development of the NK cells has not been elucidated, it has been suggested that these cells could be precursors of those with the CD $3^{-} \mathrm{CD} 16^{+} \mathrm{CD} 56^{\mathrm{dim}+}$ phenotype, which are the main NK cells in normal individuals. Increased counts of $\mathrm{NK} \mathrm{CD}^{-} \mathrm{CD} 16^{-}$ CD56 $6^{\text {bright+ }}$ cells have been reported in a group of patients after bone marrow transplant or treatment with interleukin $2,{ }^{6-8}$ suggesting that these procedures could mobilise these hypothetical precursor cells towards the circulating blood.

The phenotypes of tumour cells have often permitted the prediction of unknown links in $T$ and $B$ lymphoid differentiation. We believe that the phenotype in NK cell leukaemias could also provide clues for elucidating the ontogeny of NK cells. One antigenic characteristic common to all the NK/LGL leukaemias described in published reports, including our patient, is the lack of expression of CD7. This is a surface antigen expressed by normal $\mathrm{T}$ and NK cells. Some models postulate that in the differentiation of the NK cells, the expression of CD7 might be a very early occurrence, ${ }^{910}$ as is the case in $\mathrm{T}$ cell differentiation. Less than $2 \%$ of the NK cells in the peripheral blood of normal subjects have the $\mathrm{CD}^{-} \mathrm{CD} 56^{+}$phenotype, supporting the probability that these are early precursors of $\mathrm{CD} 7^{+} \mathrm{CD} 56^{+} \mathrm{NK}$ cells. However, the absence of CD7 in the leukaemic NK cells might indicate that this marker is expressed in NK cells following the expression of other markers, such as CD2 or CD56, which are expressed in all the cases of NK/LGL leukaemia reported to date.

HLA-DR is not expressed by the majority of normal NK cells, only by activated ones, so it should not be surprising that this feature is absent in our patient. The curious fact is that our patient is the only one who did not express HLA-DR among all the cases of NK/LGL leukaemias studied. In patients treated with interleukin 2 , a small but significant $(2-3 \%$ of peripheral blood lymphocytes) proportion of cells with the $\mathrm{CD}^{-} \mathrm{CD}^{-} \mathrm{CD} 8^{-} \mathrm{CD} 16^{-} \mathrm{CD} 56^{++}$ HLA-DR ${ }^{-}$phenotype can be measured, ${ }^{8}$ showing that this cell type exists in the peripheral blood, at least when given certain stimuli. The neoplastic cells observed in our patient could represent a leukaemic counterpart of this hypothetical NK cell precursor.

The present case had clinical and haematological features similar to typical Japanese NK/LGL leukaemia, which suggests it is the same entity presenting in a European patient. We conclude that the rare occurrence of NK/LGL leukaemia and the peculiar immunophenotype of the blast cells, which as far as we know is the first to be described, lends special interest to the present case.

1 Tefferi A, Li CY, Witzig TE, Dhodapkar MV, Okuno SH, Phyliky RL. Chronic natural killer cell lymphocytosis: a descriptive clinical study. Blood 1994;84:2721-5.

2 Imamura N, Kusunoki Y, Kawa-Ha K, Yumura K, Hara J, Oda $\mathrm{K}$, et al. Aggressive natural killer cell leukaemia lymphoma: report of four cases and review of the literature. Possible existence of a new clinical entity originating from the third lineage of lymphoid cells. Br f Haematol 1990;75: 49-59.

3 Robertson MJ, Ritz J. Biology and clinical relevance of human natural killer cells. Blood 1990;76:2421-38.

4 Soler J, Bordes R, Ortuño F, Montagud M, Martorell J, Pons C, et al. Aggressive natural killer cell leukaemia/ lymphoma in two patients with lethal midline granuloma. Br f Haematol 1994:86:659-62.

5 Parrado A, Rodríguez-Fernández JM, Casares S, Noguerol P, Plaza E, Parody R, et al. Generation of LAK cells in vitr in patients with acute leukemia. Leukemia 1993;7:1344-8.

6 Jacobs R, Stoll M, Stratmann G, Leo R, Link H, Schmidt RE. CD $16^{-} \mathrm{CD}^{-} 6^{+}$natural killer cells after bone marrow transplantation. Blood 1992;79:3239-44.

7 Weil-Hillman G, Fisch P, Prieve AF, Sosman JA, Hank JA Sondel PM. Lymphokine-activated killer activity induced by in vivo interleukin 2 therapy: predominant role for lymp in vive int phocytes with increased expression of CD2 and Leu19 Res $1989 ; 49.3680-8$

8 Parrado A. Análisis de la actividad citolítica natural y las subpoblaciones linfocitarias en las leucemias agudas: efecto in vitro e in vivo de la interleucina-2. $\mathrm{PhD}$ thesis. Seville: University of Seville, 1994.

9 Sánchez MJ, Spits H, Lanier LL, Phillips JH. Human natural killer cell committed thymocytes and their relation to the T cell lineage. $\mathcal{F}$ Exp Med 1993;178:1857-66.

10 Miller JS, Alley KA, McGlave P. Differentiation of natural killer (NK) cells from human primitive marrow progenitors in a stroma-based long-term culture system: identificatio of a CD $34^{+} 7^{+}$NK progenitor. Blood 1994;83:2594-601.
First Department of Internal Medicine, Agia Olga Hospital, Athens, Greece

C Christopoulos

K Kottoris

E Anevlavis

Choremeion Oncology

Research Laboratory, Medical School,

Athens University,

Athens, Greece

V Mikraki

Correspondence to: Dr C Christopoulos, Vas. Alexandrou 7, Kifissia,

Athens, 14561 Greece.

Accepted for publication 4 September 1996

\title{
Presence of the bcr/abl rearrangement in a patient with chronic neutrophilic leukaemia
}

\author{
C Christopoulos, K Kottoris, V Mikraki, E Anevlavis
}

absence of the Philadelphia chromosome

\section{Abstract}

An 83 year old woman presented with a myeloproliferative disorder involving the myeloid and megakaryocytic lines, and characterised by mature neutrophil leucocytosis. There was a high/normal neutrophil alkaline phosphatase activity and features compatible with a diagnosis of chronic neutrophilic leukaemia (CNL). Southern blot analysis of the patient's DNA revealed the presence of the bcr/abl rearrangement. Combined with a previous report of detection of $\mathrm{Ph}^{1}$ chromo- 
some in long term bone marrow cultures in a patient with CNL, this finding suggests that the bcr/abl hybrid gene might occasionally result in a myeloproliferative disorder with a phenotype closely resembling that of CNL.

(F Clin Pathol 1996;49:1013-1015)

Keywords: chronic neutrophilic leukaemia, myeloproliferative disorders, chronic granulocytic leukaemia, bcr/ abl rearrangement, Philadelphia chromosome.

Chronic neutrophilic leukaemia (CNL) is a rare myeloproliferative disorder, with about 40 cases reported in the literature since it was first described by Tuohey in $1920 .^{1-3}$ Seen mostly in the elderly, it is related to chronic granulocytic leukaemia (CGL) from which it is differentiated by the paucity of immature granulocytes in the peripheral blood, the increased neutrophil alkaline phosphatase activity and the absence of the Philadelphia $\left(\mathrm{Ph}^{1}\right)$ chromosome. Despite its mature phenotype, CNL seems to have a prognosis considerably worse than that of CGL.

In the few cases of CNL on which molecular cytogenetic studies have been done, the bcr/abl rearrangement has not been found. Here, we present a case of $\mathrm{Ph}^{1}$ negative, bcr/abl positive myeloproliferative syndrome with the phenotype of CNL, suggesting that this rare disorder might occasionally represent the expression of the same oncogene that is activated in CGL. We propose that the criteria for diagnosis of CNL be redefined.

\section{Case report}

An 83 year old woman was admitted to hospital for investigation of leucocytosis discovered a few days prior to her admission when she had presented with one month's history of progressive weakness, lassitude and weight loss. There was a history of mild hypertension and exertional dyspnoea of recent onset. The patient was not taking any medication. Physical examination revealed mild congestive cardiac failure but was otherwise unremarkable. Results of a full blood count were as follows: haemoglobin $12.9 \mathrm{~g} / \mathrm{dl}$; white cell count (WBC) $59.7 \times 10^{9} / 1$ with $93 \%$ neutrophils, $2 \%$ lymphocyte's, $3 \%$ monocytes, $1 \%$ myelocytes, $1 \%$ metamyelocytes; platelet count $494 \times 10^{9} / 1$. There was a right shift of the mature neutrophils with notable nuclear hypersegmentation. Occasional erythroblasts were also present in the blood film. The platelets showed notable morphological abnormalities including giant and hypogranular cells; numerous platelet clumps were present. The neutrophil alkaline phosphatase (NAP) score was 156 (normal range in our laboratory 70-160). The erythrocyte sedimentation rate was $56 \mathrm{~mm} /$ hour. Serum biochemical profile (normal ranges in brackets) was within normal limits apart from a raised urate concentration at $\mathbf{0 . 5 2}$ $\mathrm{mmol} / \mathrm{l}(0.16-0.43)$ and lactic dehydrogenase activity at $335 \mathrm{IU} / 1$ (96-176). The serum vitamin $B_{12}$ concentration was raised at $1233 \mathrm{ng} / 1$ (250-1100) with normal folate, iron and ferritin concentrations. A chest $x$ ray film showed vascular congestion and a computed tomography scan of the abdomen was normal; there was no splenomegaly or hepatomegaly. Bone marrow aspiration and biopsy samples were hypercellular with noticeably hyperplastic granulopoiesis and a myeloid:erythroid ratio of 10:1. The predominant cells were myelocytes, while the percentage of blasts was not increased $(<2 \%)$. Megakaryocytes were increased in number with active platelet production. Erythropoiesis was normal.

\section{Methods}

Chromosome analysis was performed using the RHG labelling technique. Twenty metaphases were analysed and one was karyotyped. There were no structural or numerical abnormalities in any of the metaphases analysed. The $\mathrm{Ph}^{1}$ chromosome was not detected. The bcr/abl rearrangement in haemopoietic cells aspirated from the patient's bone marrow was detected by Southern blotting. High molecular weight DNA was digested with the BglII restriction enzyme and hybridised to a $\mathrm{phl} / \mathrm{bcr}-3$ specific DNA probe (Transprobe-1, Oncogene Science) according to standard procedures. ${ }^{4}$ Autoradiography revealed the presence of an extra band confirming the existence of $\mathrm{bcr} / \mathrm{abl}$ translocation (fig 1).

Nine days after being admitted to hospital, the patient developed signs of an ilio-femoral deep vein thrombosis of the left lower extremity, which was confirmed by Doppler ultrasound. There was good response to heparin treatment followed by oral anticoagulation. At the same time hydroxyurea was introduced at a dose of $1 \mathrm{~g} /$ day, resulting in a fall in the WBC from $60 \times 10^{9} / 1$ to $16 \times 10^{9} / 1$ and the platelet count from $575 \times 10^{9} / 1$ to $170 \times 10^{9} / 1$ after two weeks of treatment. This was associated with notable symptomatic improvement. A dose of hydroxyurea of $0.5 \mathrm{~g} /$ day was required to maintain the WBC at 10-20 $\times$ $10^{9} / 1$ and the platelet count at $150-200 \times 10^{9} / 1$. The patient died suddenly at home three months after her initial presentation. A postmortem examination was not done.

\section{Discussion}

The primary myeloproliferative nature of this patient's illness was confirmed by the combination of a persistent rise in the neutrophil count in the absence of a cause of the leukaemoid reaction, a hyperplastic bone marrow myelopoiesis including the myeloid and megakaryocytic lines, raised serum $B_{12}$ and urate concentrations, a raised lactic dehydrogenase activity, and the presence of the bcr/abl rearrangement. Table 1 shows the main clinical, haematological and cytogenetic features of the case presented here against those of typical cases of CGL and CNL. The absence of splenomegaly, unusual in a myeloproliferative disorder, was thought to be because of either functional hyposplenism of old age ${ }^{6}$ or atrophy following splenic infarctions, which are a common manifestation of the thrombotic tendency associated with myeloproliferative disorders. The cytogenetic abnormality is the hallmark of CGL but this diagnosis is incompatible with the paucity of immature granulocytes in the peripheral 
Table 1 Characteristic clinical, haematological and cytogenetic features of CGL,CNL and patient DM

\begin{tabular}{|c|c|c|c|}
\hline & $C G L$ & $C N L$ & Patient DM \\
\hline Splenomegaly & Yes & Yes & No \\
\hline $\begin{array}{l}\text { Immature } \\
\text { granulocytes in } \\
\text { peripheral blood }\end{array}$ & Frequent & Rare & Rare \\
\hline NAP & Low & High & High/normal \\
\hline $\mathrm{Ph}^{1}$ chromosome & $\begin{array}{l}\text { Present } \\
85 \%\end{array}$ & Absent $^{\star}$ & Absent \\
\hline bcr/abl hybrid gene & $\begin{array}{l}\text { Present } \\
95 \%\end{array}$ & Absent & Present \\
\hline
\end{tabular}

*There is only one report of $\mathrm{Ph}^{1}$ positive $\mathrm{CNL}$ in the English literature. $^{5}$

blood, the normal myeloblast and promyelocyte numbers in the bone marrow and the high/normal NAP score. The phenotype of this myeloproliferative disorder combined with the absence of $\mathrm{Ph}^{1}$ chromosome would, in the premolecular era, be sufficient for a diagnosis of CNL. A Medline search of the English literature identified only one case of CNL in which the $\mathrm{Ph}^{1}$ chromosome was detected in long term culture. ${ }^{5}$ The bcr/abl rearrangement has been consistently absent in the few cases in which relevant studies have been done but the need for more data has also been stressed. ${ }^{3}$ The presence of the bcr/abl rearrangement in the case reported here suggests that the repertoire of the phenotypic expression of the hybrid bcr/ abl gene might include a disorder closely resembling CNL. This calls for redefinition of the diagnostic criteria for CNL to include the absence of $\mathrm{bcr} / \mathrm{abl}$, as a projection of the generally accepted requirement for absence of a $\mathrm{Ph}^{1}$ chromosome. Even so, cases like the one presented here will remain difficult to classify, reflecting the presence of a continuum within the myeloproliferative group of chronic myeloid leukaemias.

1 Lichtman MA. Chronic myelogenous leukemia and related disorders. In: Williams WJ, Beutler E, Lichtman MA, Coller BS, Kipps TJ, eds. Hematology. New York: McGrawHill, 1995:309-10.

2 Virgolini L. Leucaemia neutrofila. Revisione della letteratura. Min Med 1985;76:1951-6.

3 Zittoun R, Rea D, Ngoc LH, Ramond S. Chronic neutrophilic leukemia. A study of four cases. Ann Hematol 1994;68:55-60.

4 Southern EM. Detection of specific sequences among DNA fragments separated by gel electrophoresis. $7 \mathrm{Mol} \mathrm{Biol}$ ragments separate

5 Sanada I, Yamamoto S, Ogata M, Kawakita M, Kawano F, Fujiwara $\mathrm{H}$, et al. Detection of Philadelphia chromosome in chronic neutrophilic leukemia. fpn $\mathcal{f}$ Clin Oncol 1985;15: 553-8.

6 Zago MA, Figueiredo MS, Covas DT, Bottura C. Aspects of splenic hypofunction in old age. Klin Wochenschr 1985;63: $590-2$.

\title{
Myxoid renal cell carcinoma: histological, immunocytochemical and ultrastructural study
}

\author{
H A Birch, J M Glass, J Vale, $M$ M Walker
}

Department of

Histopathology, St

Mary's Hospital, Praed

Street, Paddington,

London W2 1NY

H A Birch

M M Walker

\section{Department of}

Urology

J M Glass

J Vale

Correspondence to: Mr Jonathan Glass.

\begin{abstract}
Renal cell carcinomas show a variety of histological features. A case of a renal tumour arising in a 44 year old African man is reported. The tumour was composed of a cobweb-like pattern of narrow anastomising tubules lined by cuboidal cells separated by a hypocellular myxoid stroma. Immunohistochemical stains were consistent with a renal cell origin. The differential diagnosis in these cases includes sarcoma.
\end{abstract}

(F Clin Pathol 1996;49:1015-1017)

Keywords: renal cell carcinoma, histological variants.

Renal cell carcinomas exhibit a wide variety of cytological and architectural appearances. Chromophilic tumours (of eosinophilic or basophilic type) usually exhibit a tubulopapillary growth pattern with cells separated by a small volume of fibrovascular stroma. ${ }^{1}$ Here, we report an unusual chromophilic renal cell carcinoma with a microtubular growth pattern and abundant myxoid stroma.

\section{Case report}

A 44 year old African man presented with intermittent loin pain and haematuria. He had been hypertensive for 10 years and had a history of childhood schistosomiasis. He was a non-smoker with no risk factors for renal o disease. There was a family history of hypertension. A renal ultrasound scan revealed a mass in the left kidney, which was confirmed on computed tomography scanning. A radical nephrectomy was performed and the patient was discharged home seven days later. $\mathrm{He}$ remains well 12 months after the operation.

\section{Pathological findings}

Macroscopically, the kidney contained a well defined rounded tumour, $3.6 \mathrm{~cm}$ in diameter, within the cortex of the upper pole, confined within the renal capsule and with a soft yellow cut surface with areas of haemorrhage. The remaining renal tissue was macroscopically normal. Five representative samples of the tumour were taken for histological examination. Microscopically, all sections showed that the tumour was composed of a cobweb-like 